\title{
The effect of a high concentrate diet and different fat sources on rumen fermentation in vitro*
}

\author{
D. Jalč ${ }^{1}$, A. Potkański², M. Szumacher-Strabel ${ }^{2}$, J. Kowalczyk ${ }^{3}$ \\ and A. Cieślak ${ }^{2}$ \\ ${ }^{1}$ Institute of Animal Physiology, Slovak Academy of Sciences \\ Soltesovej 4-6, 04001 Košice, Slovak Republic \\ ${ }^{2}$ The August Cieszkowski Agricultural University of Poznań, \\ Department of Animal Nutrition and Feed Management \\ Wotyńska 33, 60-637 Poznań, Poland \\ ${ }^{3}$ The Kielanowski Institute of Animal Physiology and Nutrition, Polish Academy of Sciences \\ 05-110 Jabtonna, Poland
}

\begin{abstract}
The experiment was carried out on a Rusitec (rumen simulation technique). The effect of diet (fresh lucerne plus maize, 40:60\%) and fat sources (linseed LO, rapeseed RO, fish FO oils, 5\% wt. wt $t^{-1}$ ) on rumen fermentation was studied. To ensure a steady-state within the Rusitec vessels a 7-day adaptation period preceded the 6-day collection period. The diet and a 5\% addition of LO, RO or FO were added to the respective fermentation vessels daily. The results showed that oil supplementation (LO, RO, FO) did not affect some basal parameters of rumen fermentation ( $\mathrm{pH}$, total VFA production, dry matter and detergent fibre digestibility), but significantly reduced the degradation of cellulose. Among the oils, mainly LO significantly reduced $\mathrm{mol} \%$ of acetate, increased the $\mathrm{mol} \%$ of propionate, however, all three oils significantly reduced the $\mathrm{A} / \mathrm{P}$ ratio. The oils supplemented to the high concentrate diet decreased $(\mathrm{P}<0.001)$ the efficiency of microbial protein synthesis.
\end{abstract}

KEY WORDS: artificial rumen, lucerne, maize, oils, rumen fermentation

\section{INTRODUCTION}

High concentrate diets usually change the environmental conditions in the rumen and extent of biohydrogenation and consequently, the type of fatty acids that are formed. Manipulation of rumen fermentation by including fatty acids may inhibit rumen microbial synthesis or fibre digestion (Jenkins, 1993). In this study,

\footnotetext{
* Supported by the Grant Agency of the Slovak Academy of Sciences, Grant No. 2/6174/6 and the State Committee for Scientific Research (Poland), Grant No. 3 P06Z 05923

${ }^{1}$ Corresponding author: e-mail: jalcd@saske.sk
} 
the effect of a high concentrate diet (fresh lucerne plus maize, 40:60\%) and of this diet supplemented with rapeseed, linseed or fish oil $\left(5 \% \mathrm{wt}^{-} \cdot \mathrm{tt}^{-1}\right)$ on rumen fermentation in an artificial rumen was studied.

\section{MATERIAL AND METHODS}

\section{Animals and diets}

The rumen simulation technique and rumen fluid supply of Rusitec equipment and chemical composition of feed was described by Jalč et al. (2006a).

The animals were fed with a fresh lucerne ( $480 \mathrm{~g}$ of DM) and maize ( $720 \mathrm{~g}$ of DM) diet. In the Rusitec, all of the fermentation vessels were supplied with $12 \mathrm{~g}$ (3.6 g DM) of fresh lucerne and $6.2 \mathrm{~g}(5.4 \mathrm{~g} \mathrm{DM})$ of crushed maize together with the addition of, $5 \% \mathrm{wt} \cdot \mathrm{wt}-1$ : LO, RO and FO.

\section{Measurements and chemical analyses}

The experiment in the Rusitec lasted 13 days. To ensure a steady state within the vessels, a 7-day adaptation period preceded the 6-day collection period. On days 813 the samples were collected and analysed for volatile fatty acids (VFA), nitrogen and ammonia nitrogen $\left(\mathrm{NH}_{3}-\mathrm{N}\right)$ in effluent; dry matter, NDF and ADF, ash and nitrogen in feed and feed refusals (undigested feed samples). The other fermentation variables - fermentation efficiency (E), organic matter fermented (OMF), nitrogen incorporated by microflora $\left(\mathrm{N}_{\mathrm{M}}\right)$, and efficiency of microbial protein synthesis (EMS) - were calculated according to the stoichiometry of rumen fermentation. The detailed procedures are described in a previous study (Jalč and Čertík, 2005).

\section{Statistical analysis}

The means of results from treatments were compared by one-way analysis of variance (ANOVA). Treatment means were statistically compared by the TukeyKramer multiple comparison test. The tables give the group means and standard error of the means.

\section{RESULTS AND DISCUSSION}

Fermentation of the diets was carried out at $\mathrm{pH}$ 6.94-7.09 and the $\mathrm{pH}$ values were similar in all oil-supplemented diets compared with the control (Table 1). In the experiment, the concentration of $\mathrm{NH}_{3}-\mathrm{N}$ remained in the range $13-21 \mathrm{mg} \cdot 100 \mathrm{ml}^{-1}$ 
and it was not affected by oil supplementation (Table 1). The concentration of ammonia nitrogen was significantly lower in LO in comparison with the control. The rumen degradation of dry matter (DMD) after $48 \mathrm{~h}$ of incubation in fermentation fluid was slightly (not significantly) reduced with the FO or slightly increased with LO and RO supplements. Supplemented lipids mainly reduce rumen degradation of fibre by physically coating fibre, which inhibits rumen microbial activity. The digestibility of NDF, ADF and hemicellulose in the high concentrate diet showed no significant differences between control and oil supplemented diets (Table 1). A reduction $(\mathrm{P}<0.005)$ of cellulose degradability was found in the oilsupplemented diets compared with the control. Some authors (Wachira et al.,

Table 1. Effect of the diet consisting of fresh lucerne and maize (40:60\%) and supplemented with different oils on the rumen fermentation pattern in a Rusitec (n-6)

\begin{tabular}{|c|c|c|c|c|}
\hline \multirow[t]{2}{*}{ Item } & \multicolumn{4}{|c|}{ Type of added oil $\left(5 \% \mathrm{wt}^{\cdot} \mathrm{wt}^{-1}\right)$} \\
\hline & control $^{\mathrm{a}}$ & $\mathrm{LO}^{\mathrm{b}}$ & $\mathrm{RO}^{\mathrm{c}}$ & $\mathrm{FO}^{\mathrm{d}}$ \\
\hline$\overline{\mathrm{pH}}$ & $7.02 \pm 0.03$ & $6.96 \pm 0.04^{\mathrm{d}}$ & $6.94 \pm 0.05$ & $7.09 \pm 0.04$ \\
\hline $\mathrm{DMD}, \%$ & $68.74 \pm 2.56$ & $70.79 \pm 2.47$ & $75.04 \pm 2.63$ & $65.95 \pm 2.43$ \\
\hline NDF, $\%$ & $64.55 \pm 2.55$ & $66.27 \pm 2.81$ & $70.65 \pm 2.24$ & $62.13 \pm 2.12$ \\
\hline $\mathrm{ADF}, \%$ & $67.15 \pm 2.48$ & $71.92 \pm 2.26$ & $69.86 \pm 2.46$ & $58.28 \pm 2.36^{\mathrm{b}}$ \\
\hline Hemicellulose, $\%$ & $62.52 \pm 2.46$ & $60.95 \pm 2.52$ & $71.34 \pm 2.38$ & $65.82 \pm 2.45$ \\
\hline Cellulose, $\%$ & $90.19 \pm 2.52^{b, c, d}$ & $75.91 \pm 2.36$ & $78.56 \pm 2.45$ & $72.13 \pm 2.21$ \\
\hline $\mathrm{NH}_{3}-\mathrm{N}, \mathrm{mg} \cdot 100 \mathrm{ml}$ & $19.56 \pm 0.78^{b}$ & $13.31 \pm 0.82^{\mathrm{c}, \mathrm{d}}$ & $19.26 \pm 0.92$ & $20.57 \pm 0.85$ \\
\hline VFA, mmol $\cdot$ day $^{-1}$ & $35.86 \pm 2.56$ & $36.27 \pm 2.45$ & $40.52 \pm 2.36$ & $34.79 \pm 2.15$ \\
\hline Acetate & $19.33 \pm 1.62$ & $15.88 \pm 1.81^{\mathrm{c}}$ & $22.37 \pm 1.47^{\mathrm{d}}$ & $17.88 \pm 1.69$ \\
\hline Propionate & $5.03 \pm 0.27$ & $7.63 \pm 0.35$ & $6.94 \pm 0.52$ & $5.66 \pm 0.49$ \\
\hline n-butyrate & $7.35 \pm 0.11$ & $7.35 \pm 0.18$ & $6.96 \pm 0.14$ & $6.88 \pm 0.21$ \\
\hline $\mathrm{A} / \mathrm{P}$ ratio & $3.84 \pm 0.12^{\mathrm{c}}$ & $2.26 \pm 0.09^{\mathrm{a}, \mathrm{c}, \mathrm{d}}$ & $3.25 \pm 0.10$ & $3.17 \pm 0.12^{\mathrm{a}}$ \\
\hline Acetate, $\mathrm{mol} \%$ & $53.83 \pm 0.82$ & $43.69 \pm 0.25^{\mathrm{a}, \mathrm{c}, \mathrm{d}}$ & $55.21 \pm 0.62^{\mathrm{d}}$ & $51.29 \pm 0.76$ \\
\hline Propionate, $\mathrm{mol} \%$ & $14.04 \pm 0.14$ & $20.28 \pm 0.19^{\mathrm{a}}$ & $17.06 \pm 0.51$ & $16.19 \pm 0.41$ \\
\hline n-butyrate, mol\% & $20.51 \pm 0.47$ & $20.86 \pm 1.61$ & $17.23 \pm 1.0$ & $19.94 \pm 0.84$ \\
\hline E, \% & $74.21 \pm 0.36^{\mathrm{b}}$ & $77.48 \pm 0.42^{\mathrm{c}}$ & $74.81 \pm 0.46$ & $75.16 \pm 0.42^{\mathrm{b}}$ \\
\hline OMF, g day ${ }^{-1}$ & $3.78 \pm 0.21$ & $4.38 \pm 0.18^{\mathrm{a}}$ & $4.12 \pm 0.19$ & $3.95 \pm 0.17^{\mathrm{b}}$ \\
\hline $\mathrm{N}_{\mathrm{M}}, \mathrm{mg} \cdot$ day $^{-1}$ & $111.95 \pm 4.25$ & $113.11 \pm 4.12$ & $96.01 \pm 5.12$ & $94.77 \pm 4.35$ \\
\hline EMS, $\mathrm{mg} \cdot \mathrm{g}^{-1}$ & $29.80 \pm 1.03^{b, c, d}$ & $25.82 \pm 1.27$ & $23.40 \pm 1.22$ & $23.99 \pm 1.45$ \\
\hline
\end{tabular}

LO - linseed oil; RO - rapeseed oil; FO - fish oil; DMD - dry matter digestibility; NDF - neutral detergent fibre; ADF - acid detergent fibre; E - energetic efficiency of volatile fatty acids; OMF - organic matter fermented; $\mathrm{N}_{\mathrm{M}}$ - nitrogen incorporated by microflora; EMS - efficiency of microbial protein synthesis; \pm SEM (standard error of mean); values in a row with different superscripts $\left({ }^{\mathrm{a}, \mathrm{b}, \mathrm{c}, \mathrm{d}}\right)$ differ at $\mathrm{P}<0.05$

2000) have reported negative effects of polyunsaturated fatty acids (PUFA), fish oil in particular, on fibre digestion in sheep and beef cattle. According to our results, the oils did not affect total VFA production or production of acetate, propionate and n-butyrate $\left(\mathrm{mmol}^{\left.-d_{a y}{ }^{-1}\right)}\right.$ in high concentrate diets. Nonetheless, the molar 
proportions $(\mathrm{mol} \%)$ of acetate were significantly reduced with LO and FO or increased $(\mathrm{P}<0.001)$ with RO (Table 1$)$. Propionate $(\mathrm{mol} \%)$ was significantly increased with LO or slightly increased with FO and RO to about $6.2,2.1$ and $3.0 \%$. Calculation of acetate to propionate production showed a significant decrease of the A/P ratio in all oil-supplemented diets. The energetic efficiency of VFA (E,\%) was significantly increased with LO and slightly $(\mathrm{P}>0.05)$ increased with the RO and FO supplements. According to our results, the oils supplemented to high concentrate diet significantly decreased EMS (\%). Microbial nitrogen production and the efficiency of microbial protein synthesis were also reduced by linseed and fish oil supplementations in sheep (Wachira et al., 2000).

\section{CONCLUSIONS}

Supplementing oil (LO, RO, FO) up to $5 \%$ in DM to a high concentrate diet did not affect some parameters of rumen fermentation $(\mathrm{pH}$, dry matter and detergent fibre digestibility, total VFA production). Only linseed oil significantly reduced the $\mathrm{mol} \%$ of acetate and increased the mol\% of propionate. Rapeseed and fish oil supplementation slightly but not significantly affected the molar proportions of acetate to propionate. The oils supplemented to the high concentrate diet significantly $(\mathrm{P}<0.001)$ decreased the efficiency of microbial protein synthesis.

\section{REFERENCES}

Czerkawski J.W., Breckenridge G., 1977. Design and development of a long term rumen simulation technique (Rusitec). Brit. J. Nutr. 38, 371-384

Jalč D., Čertík M., 2005. Effect of microbial oil, monensin and fumarate on rumen fermentation in artificial rumen. Czech J. Anim. Sci. 50, 467-472

Jalč D., Potkański A., Szumacher-Strabel M., Kowalczyk J., Cieślak A., 2006a. The effect of a forage diet and different fat sources on rumen fermentation in vitro. J. Anim. Feed Sci. 15, Suppl. 1, 129-134

Jenkins T., 1993. Lipid metabolism in the rumen. J. Dairy Sci. 76, 3851-3863

Wachira A.M., Sinclair L.A., Wilkinson R.K., Hallett K., Enser M., Wood J.D., 2000. Rumen biohydrogenation of n-3 polyunsaturated fatty acids and their effects on microbial efficiency and nutrient digestibility in sheep. J. Agr. Sci. 135, 419-428 